\title{
PEMILAHAN SAMPAH DENGAN MANUAL PILAH SAMPAH UNTUK MENDUKUNG PERKEMBANGAN BANK SAMPAH BERBEK MANDIRI DI DESA BERBEK KECAMATAN WARU KABUPATEN SIDOARJO PROPINSI JAWA TIMUR
}

\author{
Sri Widyastuti ${ }^{1 *}$, Setyo Purwoto ${ }^{1}$, Pungut ${ }^{1}$ \\ ${ }^{1}$ Program Studi Teknik Lingkungan Fakultas Teknik Sipil dan Perencanaan \\ *Email : sriwidyastuti@unipasby.ac.id
}

\begin{abstract}
Abstrak
Masyarakat di Desa Berbek Kecamatan Waru Kabupaten Sidoarjo belum melakukan pengelolaan sampah dengan baik dan benar. Sampah dibuang begitu saja ke Tempat Pembuangan Sampah Sementara (TPS) atau dibakar meskipun telah ada Bank Sampah. Tujuan pelaksanaan Pengabdian Masyarakat adalah sosialisasi dan pelatihan kepada masyarakat desa Berbek untuk dapat memilah sampah, mengenali jenis jenis sampah yang bernilai ekonomi sehinga bisa di tabung di Bank Sampah dan residu yang boleh masuk ke TPST / TPA. Pemilahan dan pengenalan jenis sampah dengan menggunakan Manual Pilah Sampah . Metoda pelaksanaan pengabdian : sosialisasi, pelatihan dan praktek langsung. Hasil yang di peroleh dari pelaksanaan pengabdian adalah warga masyarakat melakukan pemilahan sampah dan menyetorkan sampah kering ke Bank Sampah.
\end{abstract}

\section{Kata kunci : Pemilahan Sampah, Manual Pilah Sampah, Desa Berbek}

\section{ABSTRACT}

The problem that arises in Berbek Village, Waru District, Sidoarjo Regency is that the community has not carried out waste management properly. Garbage is simply thrown into a Temporary Waste Disposal Site (TPS) or burned even though there is a Trash Bank. The purpose of implementing Community Service is training and outreach to the people of Berbek village to be able to sort waste, recognize the types of waste that have economic value so that they can be cached at the Waste Bank and the residue that can enter TPST / TPA. Service implementation methods: socialization, training and hands-on practice. The results obtained by the community members carry out waste sorting and deposit dry waste to the Trash Bank.

Keywords : Waste Sorting, Waste Sorting Manual, Berbek Village

Peningkatan jumlah penduduk, pola konsumsi yang berubah serta pola hidup masyarakat berpengaruh terhadap jumlah timbulan sampah. Tidak hanya jumlah timbulan yang semakin naik, namun juga terjadi perubahan jenis komposisi dan karakteristik sampah. (Sistem Informasi

\section{PENDAHULUAN}

Pengelolaan Sampah Nasional Direktorat Pengelolaan Sampah Direktorat Jenderal Pengelolaan Sampah, Limbah \& B3 Kementerian Lingkungan Hidup dan Kehutanan,2020 ). Daya beli masyarakat yang semakin tinggi juga berpengaruh terhadap jumlah dan jenis limbah yang di 
hasilkan. Peningkatan pendapatan tidak di ikuti denagn tingkat kepedulian terhadap sampah yang di hasilkan (Laporan IPKLH,2018).

Pengelolaan terhadap sampah yang di hasilkan masih tetap mengacu kepada pola lama yang tidak ramah lingkungan. Pengelolaan sampah masih di anggap sebagai tanggung jawab pemerintah. Masyarakat merasa hanya cukup membayar retribusi, maka kebersihan lingkungan dianggap menjadi beban tanggung jawab pemerintah untuk mengurusi dan membereskan .

Desa Berbek Kecamatan Waru Kabupaten Sidoarjo mayoritas penduduknya bermata pencaharian sebagai petani dan pedagang. Total penduduk Desa Berbek berjumlah 3.570 jiwa yang terdiri dari laki-laki sebanyak 1.821 jiwa dan perempuan berjumlah 1.749 jiwa dengan dengan luas wilayah $972,4 \mathrm{~km}^{2}$. Potensi desa yang dimiliki oleh Desa Berbek adalah berupa persawahan (Kabupaten Sidoarjo Dalam Angka, 2020 ).
Kegiatan rumah tangga menghasilkan limbah padat yang berupa sampah organik maupun anorganik. Permasalahan yang muncul di Desa Berbek Kecamatan Waru Kabupaten Sidoarjo adalah masyarakat belum melakukan pengelolaan sampah dengan baik dan benar. Sampah dibuang begitu saja ke Tempat Pembuangan Sampah Sementara (TPS) atau dibakar di lahan kosong. Berdasarkan Undang-undang No. 18 Tahun 2008 tentang Pengelolaan Sampah dinyatakan bahwa sampah dipilah di sumbernya. Pola pengelolaan sampah harus berbasis masyarakat, tidak hanya menggantung pada kinerja pemerintah. Pola pengelolaan berbasis masyarakat selain lebih murah juga akan mudah dilakukan, karena sampah sudah di kelola sejak dari sumbernya akan lebih mudah dan murah penanganannya serta bernilai ekonomis (Anonim. 2005). Pola pemberdayaan tersebut yang harus di sampaikan kepada masyarakat . Pola pengelolaan sampah berbasis masyarakat dapat dilihat pada gambar berikut

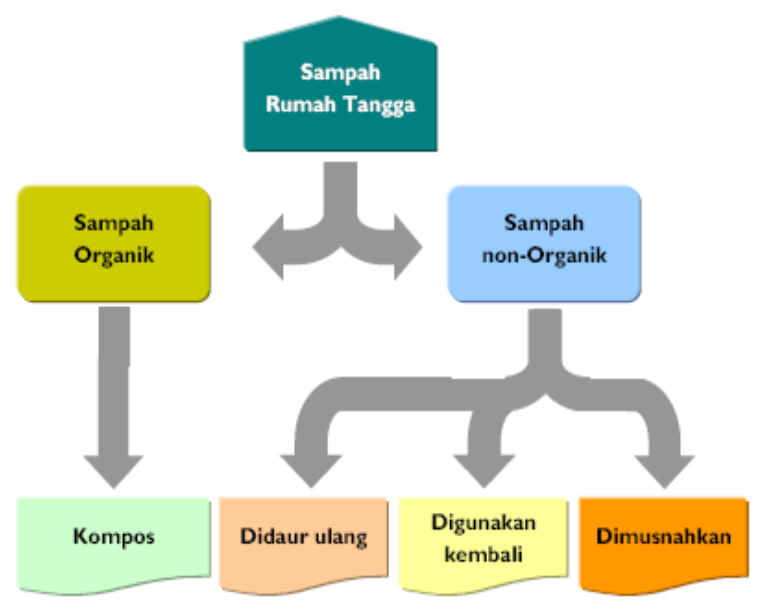

Gambar.1. Sistem Pengelolaan Sampah Berbasis Masyarakat (ESP (Environmental Services Program), 2008)

Keluhan tersebut yang disampaikan oleh Ibu Yana Ketua Bank Sampah Berbek Mandiri, ada $50 \%$ warga yang tidak mau memilah sampahnya. Membuang sampah sembarang terutama popok bekas maupun sisa pembuatan masakan di warung makan bercampur dengan sampah kering yang bernilai ekonomis karena bisa di jual maupun di daur ulang. Sehingga meskipun telah ada Bank Sampah, namun kondisi lingkungan masih saja belum bersih, sehat dan secara estetika masih belum baik. Sehingga perlu dilakukan pemberdayaan tentang pemilahan sampah menggunakan manual pemilahan. Dalam Manual pemilahan dikenalkan jenis jenis sampah 
terutama sampah kering yang bernilai ekonomi. Selain itu juga diberikan pemahaman untuk memilih kemasan yang dapat djual lagi atau di daur ulang, sehingga tidak asal beli produk untuk di konsumsi namun juga memperhatikan jenis kemasan nya (Wildayanti, 2020). Metode kegiatan yang dilakukan adalah dengan melakukan kegiatan pemberdayaan dan pelatihan kepada ibu-ibu rumah tangga di lokasi kegiatan Untuk jenis sampah anorganik, dilakukan pemilahan kemudian setelah terkumpul di tabung di Bank Sampah, sedangkan sampah organik dimasukkan ke dalam keranjang takakura atau komposter. Berdasarkan latar belakang di atas, maka diperlukan pelatihan dan sosialisasi kepada masyarakat desa Berbek untuk dapat memilah sampah, mengenali jenis jenis sampah yang berniali ekonomi sehinga bisa di tabung di Bank Sampah dan residu yang boleh masuk ke TPST / TPA.

\section{METODA PELAKSANAAN}

Sampah yang dihasilkan pada daerah Desa Berbek Kecamatan Waru Kabupaten Sidoarjo selain berasal dari kegiatan rumah tangga yang berupa sampah kering, juga dari sisa sayur dari usaha warung yang merupakan salah satu dari usaha warganya. Sebagian besar masyarakat Desa Berbek masih belum mengolah sampah yang dihasilkan dari rumah tangga dengan baik. Pengolahan sampah masih mengandalkan kebudayaan lama, dimana sampahnya masih dibuang ke lingkungan tanpa di olah terlebih dahulu terutama di buang ke sungai yang melintas di Desa Berbek . Bahaya dari tumpukan sampah tentunya sudah jelas. Jika ini tidak ditangani dengan baik dan benar, maka bukan tidak mungkin masyarakat Desa Berbek akan mudah terjangkiti oleh penyakit yang bersumber dari sampah. Hampir $60 \%$ warga Desa Berbek adalah pendatang yang bekerja di Kawasan Industri Berbek. Mereka tinggal dengan sistem in de kost maupun kontrak. Bekerja dengan sistem shift selama 8 jam, maka pada umumnya mereka tidak memasak sendiri, sehingga warung makan sangat banyak di daerah Berbek. Namun akibatnya limbah sisa konsumsi untuk pembuatan masakan di warung sangat melimpah. Selain itu banyak keluarga muda yang bekerja, sehingga yang memiliki anak cenderung banyak menggunakan popok sekali pakai. Pembuangan popok sekali pakai, tidak mengindahkan kesehatan dan estetika, popok bekas di buang begitu saja di tempat sampah, tanpa melakukan upaya untuk pencucian terlebih dahulu, tercampur dengan sampah yang lain. Akibatnya sampah menjadi sampah campur yang tidak bisa di manfaatkan dengan baik

Sebelum pelaksanaan sosialisasi, pemberdayaan dan pelatihan dilakukan pre test untuk mengetahui apakah pelaksanaan program berjalan dengan baik dan materi di fahami oleh masyarakat Desa Berbek. Dalam kegiatan ini, dilakukan pemilahan pada sampah sisa konsumsi berupa sampah basah, sedangkan untuk sampah kering rumah tangga yang meliputi plastik, kertas dan kaleng baru sebatas dikelola, yaitu dengan memilah-milah sampah, mengumpulkan kemudian ditabung di Bank Sampah atau dimanfaatkan kembali untuk sampah yang masih bisa dipakai kembali (reuse) (Anonim, 2003). Pola pemilahan sampah yang dilakukan adalah sebagai berikut 


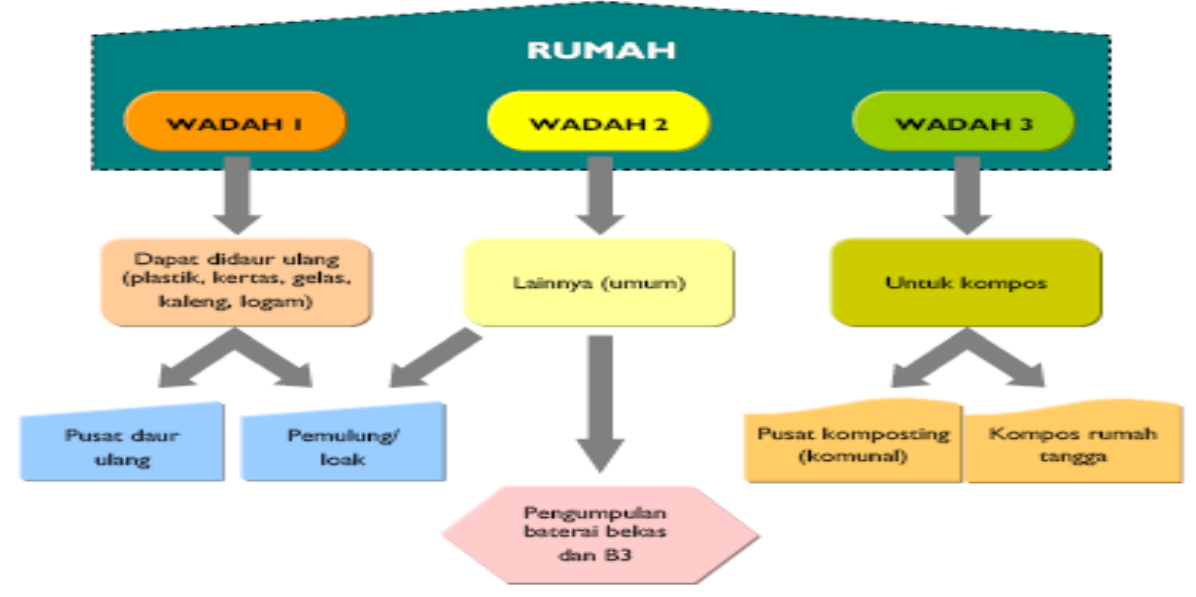

Gambar.2. Pola Pemilahan Sampah

(ESP (Environmental Services Program, 2008 )

Metode Pelaksanaan yang dilakukan berkaitan dengan (1) Pendidikan di Masyarakat, yaitu dengan memberikan penyuluhan untuk meningkatkan pemahaman serta kesadaran tentang pilah sampah (2) Pelatihan, untuk menghasilkan keterampilan memilah sampah dengan menggunakan Manual Pilah Sampah (3) kegiatan yang memberikan pendampingan terhadap kelompok mitra. Program PPM ini dilaksanakan sesuai deskripsi operasional kegiatan Program Pengabdian pada Masyarakat di Desa Berbek Kecamatan Waru Kabupaten Sidoarjo yaitu : 1. Pemberian pre test materi tentang Pemilahan Sampah, 2. Mengubah pola pikir pengelolaan sampah dengan melakukan Pemilahan sampah berdasarkan jenisnya, 3. Praktek Pemilahan Sampah dengan menggunakan Manual Pilah Sampah, 4. Post Test berkaitan dengan materi yang telah di berikan, 5 . Pendampingan dan 6. Evaluasi Untuk mengukur efektifitas program PPM ini, maka digunakan metode penyuluhan selanjutnya dilakukan pengamatan di lapangan selama 2 bulan untuk melihat hasil yang diperoleh setelah sosialisasi lingkungan (Asosiasi Pengusaha Daur Ulang Plastik, 2020). Selanjutnya dilakukan proses pengadaan alat dan bahan oleh tim pelaksana PPM sepenuhnya telah disiapkan oleh tim dosen dan dibantu oleh mahasiswa sebagai pembantu pelaksana PPM. berakhir. Gambaran teknologi yang akan diterapkan untuk menyelesaikan masalah, yaitu pemilahan sampah rumah tangga sebagai upaya menciptakan kampung sadar lingkungan yang ada di Desa Berbek Kecamatan Waru Kabupaten Sidoarjo denagn menggunakan manual pemilahan . Manual pemilahan berupa gambar gambar untuk mengenali jenis sampah sisa konsumsi yang berupa bungkus produk, yang bisa di daur ulang dan masih bernilai ekonomi . Adapun perincian pelaksanaan program PPM adalah sebagai berikut Persiapan survei lokasi dilakukan oleh Tim dosen bersama dengan tim LPPM Universitas PGRI Adi Buana Surabaya. Berdasarkan hasil survei tampak permasalahan yang perlu segera ditangani yaitu sampah rumah tangga dan sampah sisa pembuatan makanan warung yang dihasilkan oleh ibu rumah tangga di Desa Berbek dan tidak dilakukan pemilahan dan pengolahan terlebih dahulu. Hal ini dapat mengakibatkan pencemaran lingkungan. Kurangnya pemahaman warga akan metode pengolahan sampah rumah tangga, menjadi indikator utama suatu limbah tidak terolah dan mencemari Bahan utama yang disiapkan dalam kegiatan ini merupakan peralatan untuk pemilahan sisa pembuatan konsumsi Manual book proses pemilahan buatan kemudian akan diserahkan ke warga desa untuk dimanfaatkan oleh kelompok ibu PKK. Manual book yang dibutuhkan telah 
disiapkan oleh tim dosen di prodi Teknik Lingkungan Universitas PGRI Adi Buana Surabaya. Manual book proses pemilahan yang diserahkan ke warga desa untuk memilah sampah sisa konsumsi di Desa Berbek Kecamatan Waru Kabupaten Sidoarjo. Berikut salah satu bagian dari Manual Pilah Sampah .

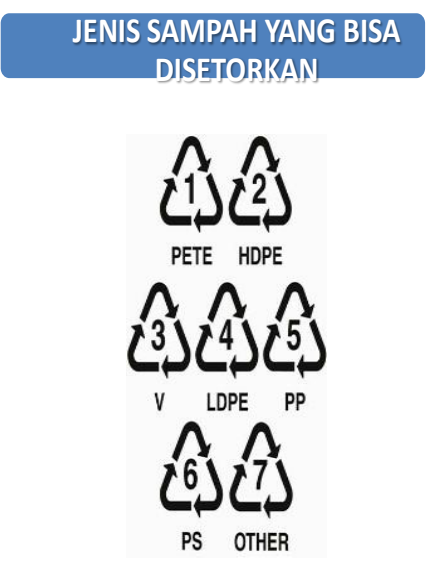

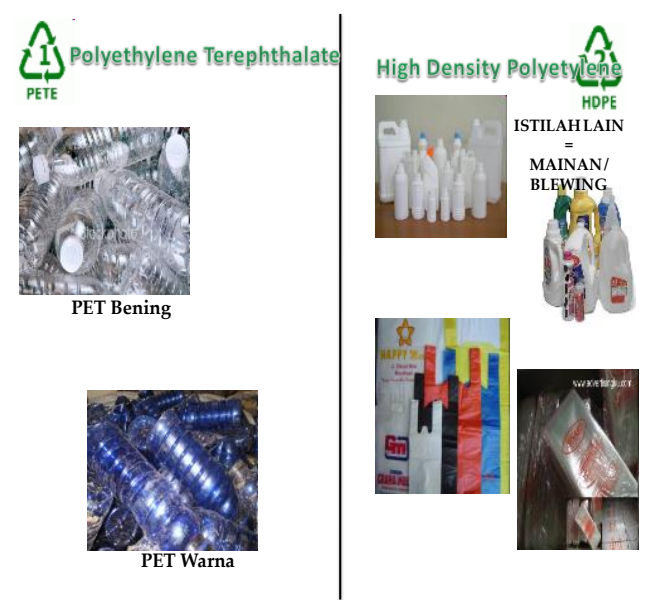

Gambar 3. Manual Pilah Sampah

Pengabdian dimulai dengan tema besarnya adalah pemilahan sampah sisa konsumsi. Disamping mensosialisasikan cara memilah dari sampah sisa konsumsi sampah rumah tangga, masyarakat juga melakukan simulasi secara langsung untuk memilah sampah rumah tangga yang dihasilkan dari rumah masing-masing. Produk akhir yang dihasilkan diharapkan nanti akan menunjang perekonomian masyarakat Desa Berbek. Penyuluhan pemilahan sampah sisa pembuatan konsumsi, maka diharapkan dapat menumbuhkan kesadaran warga akan pentingnya kelestarian lingkungan terutama dalam memilah dan mengolah sampahnya

\section{HASIL DAN PEMBAHASAN}

Pengabdian dilakukan dalam beberapa tahapan pelaksanaan, tahapan pertama adalah sosialisasi tentang tata cara pemilahan sampah sisa konsumsi selanjutnya pelatihan pemilahan sampah kering denagn menggunakan maual pilah sampah. Sampai dengan saat ini, sampah sisa sayur mayur yang tergolong sampah organik rumah tangga ini belum di pilah dan di olah. Sampah sisa pembuatan makanan di warung hanya dibuang begitu saja, padahal sampah ini dapat digunakan sebagai bahan baku pembuatan pupuk organik. Hal ini masyarakat belum menyadari bahwa ada manfaat yang bisa diperoleh dari sampah sisa konsumsi tersebut jika diolah. Seandainya masyarakat Desa Berbek bisa mengolah limbah sampah sisa pembuatan konsumsi baik basah maupun kering menjadi sesuatu produk yang berguna, maka dapat meningkatkan perekonomian masyarakat setempat. Untuk meningkatkan perekonomian masyarakat Desa Berbek, tim pelaksanaan PPM mengadakan sosialisasi yang berhubungan dengan peningkatan perekonomian masyarakat Desa Berbek. 


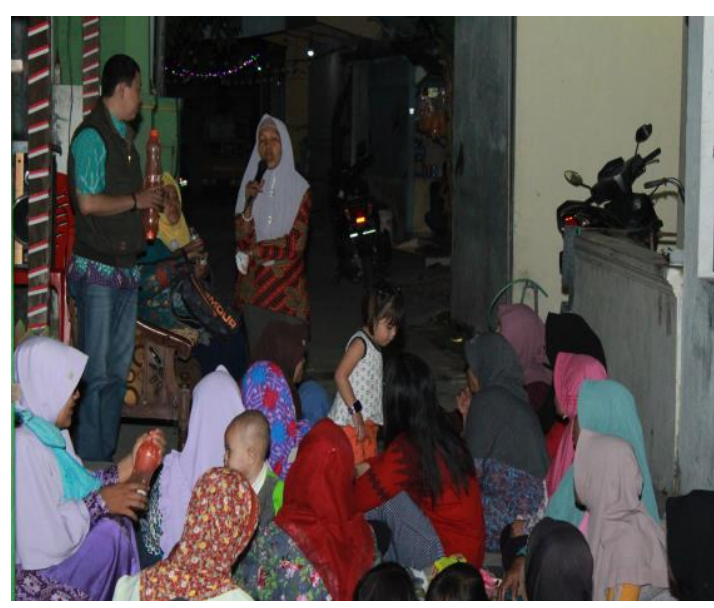

Gambar 4. Sambutan dari Ketua Kader Lingkungan Desa Berbek

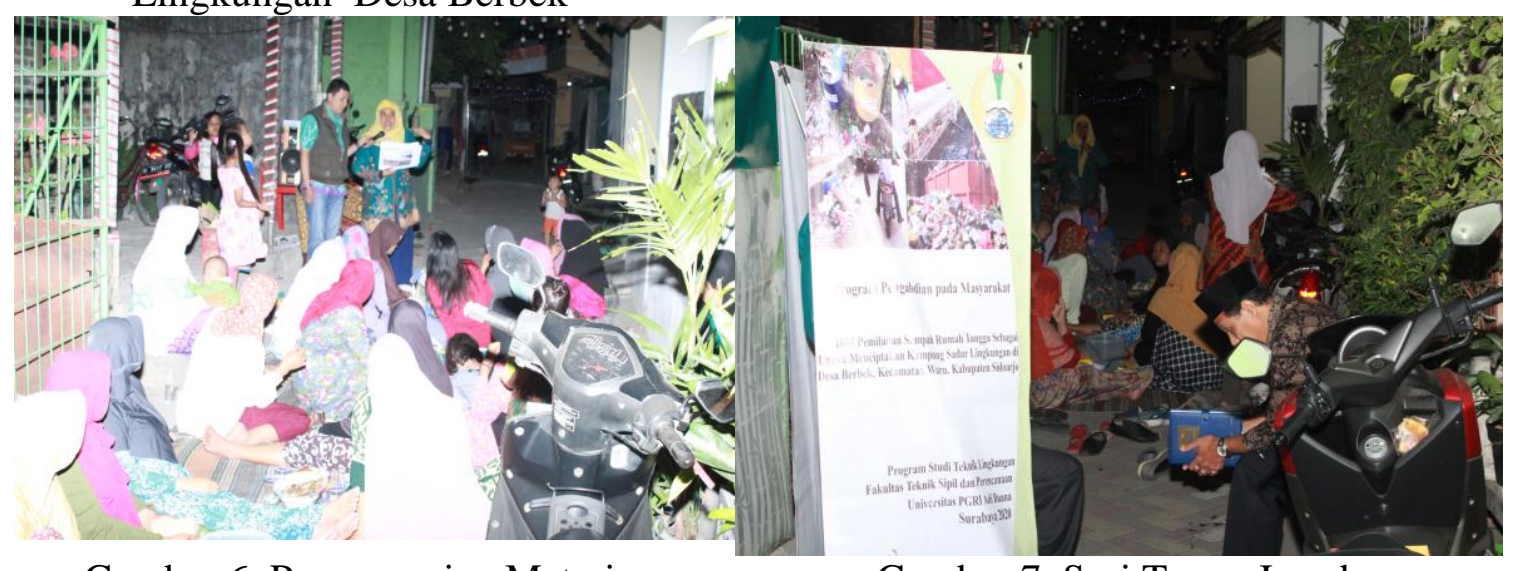

Gambar 6. Penyampaian Materi Pemilahan Sampah

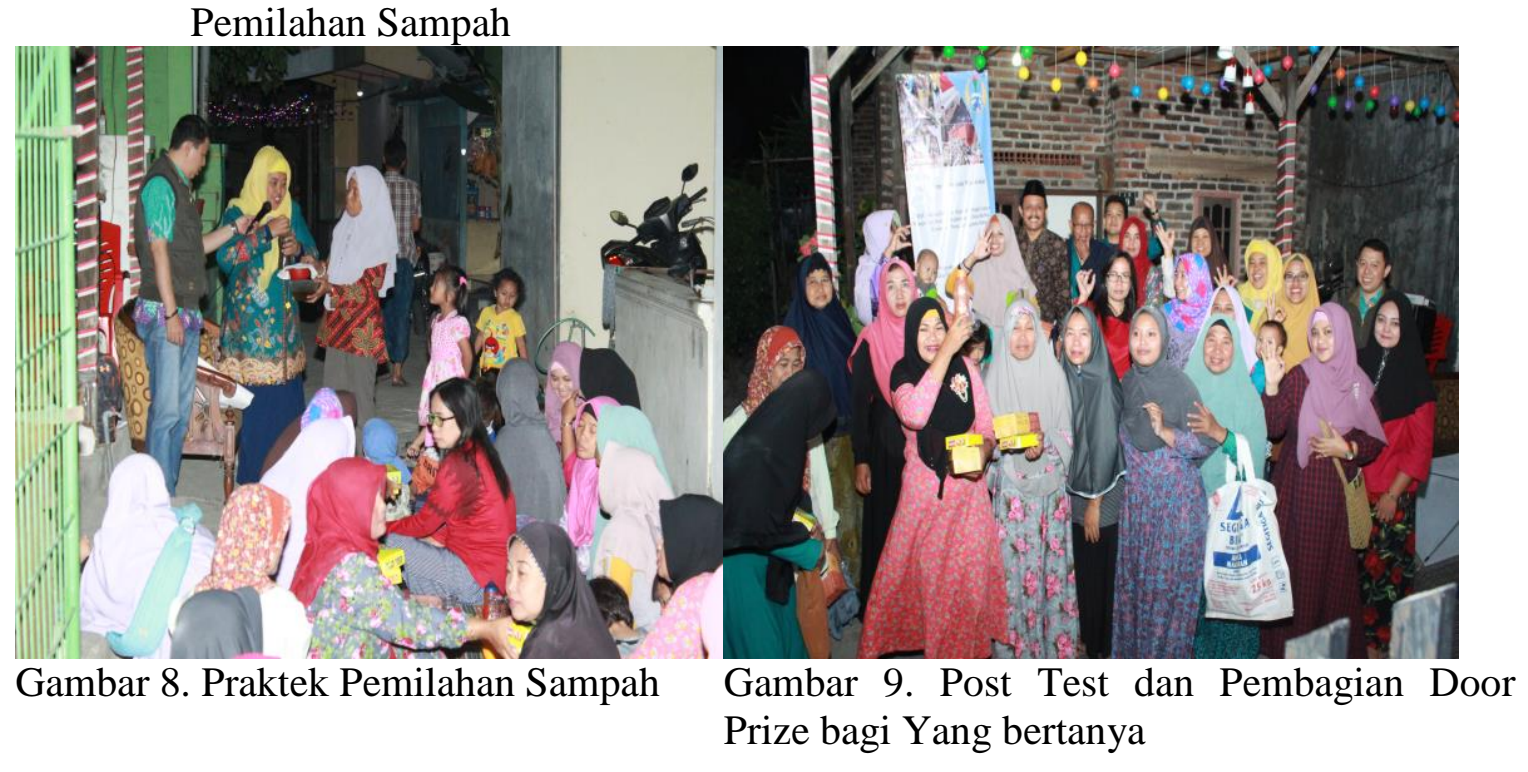

Gambar 8. Praktek Pemilahan Sampah

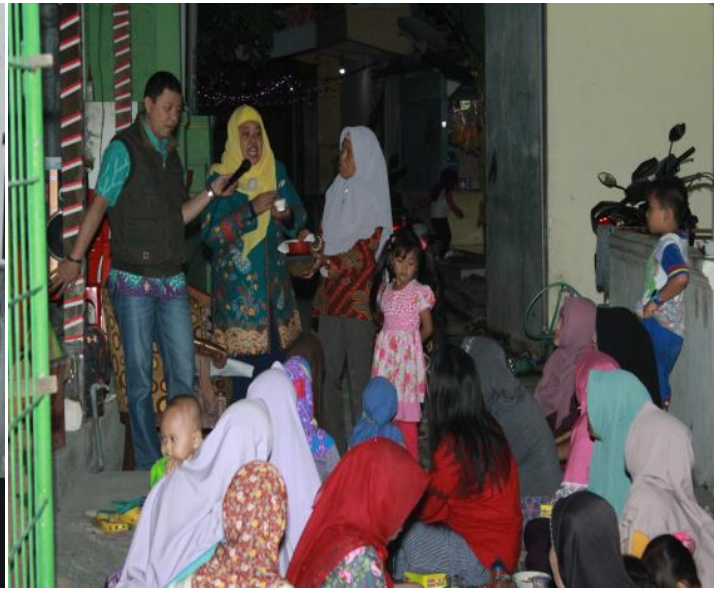

Gambar 5. Pelaksanaan Pre Test

Gambar 7. Sesi Tanya Jawab 

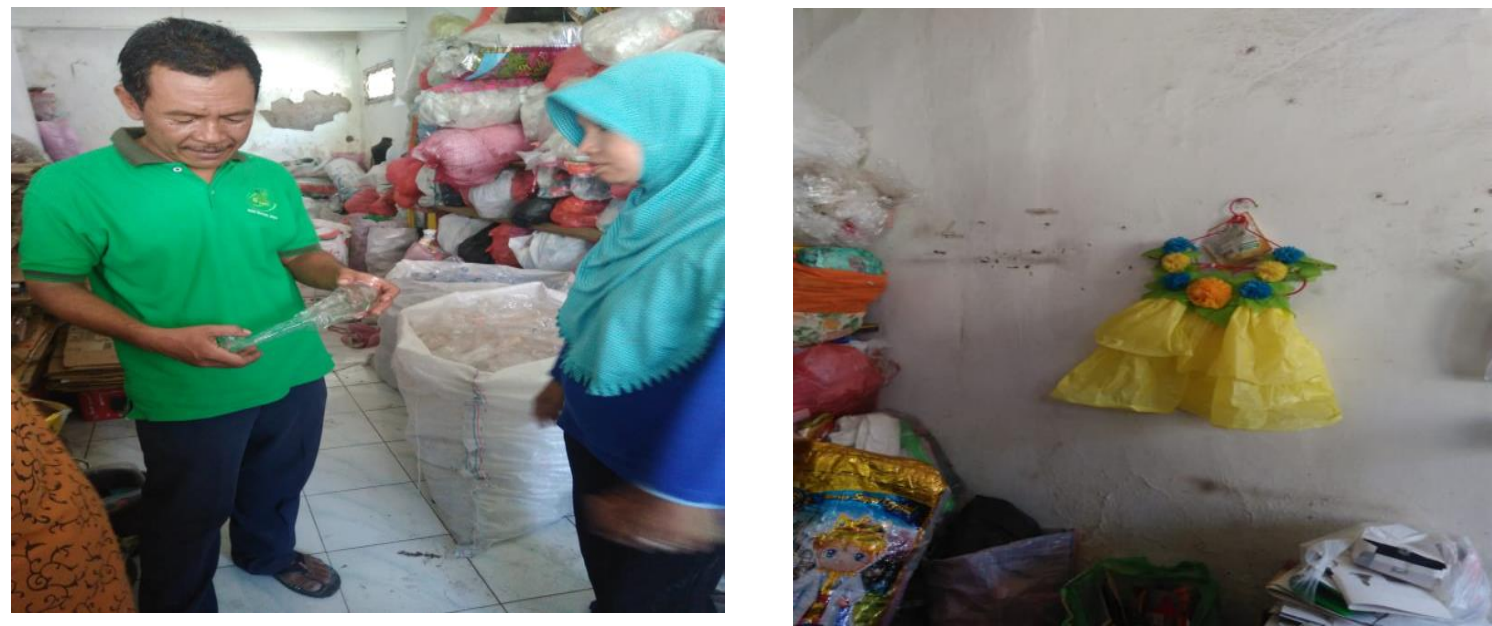

Gambar 10. Pendampingan dan produk daur ualng

Hasil pelaksanaan Pengabdian Pada Masyarakat (PPM) adalah sebagai berikut: Pemantauan pelaksanaan dilakukan setelah satu minggu pelaksanaan penyuluhan dan pelatihan di Desa Berbek. Pemantauan dilakukan dengan cara meninjau langsung ke Desa Berbek. Pemantauan ini dilakukan oleh tim PPM Dosen Teknik Lingkungan, bersama dengan aparat desa dan tim PKK. Aparat desa dan kader PKK cukup optimal dalam memanfaatkan manual pemilahan untuk mengidentifikasi jenis sampah yang bernilai ekonomis . Hasil yang didapatkan dari proses pemantauan adalah beberapa warga Desa Berbek sudah melaksanakan dengan baik terkait dengan apa yang didapatkan selama penyuluhan.

Tabel 1 Hasil Post Test

\begin{tabular}{|l|l|c|c|}
\hline \multirow{2}{*}{ No } & \multicolumn{1}{|c|}{ Pertanyaan } & \multicolumn{1}{|c|}{ Persentase (\%) } \\
\cline { 2 - 4 } & \multicolumn{1}{|c|}{ Ya } & Tidak \\
\hline 1. & $\begin{array}{l}\text { Apakah warga masyarakat Desa Berbek membuang sampah } \\
\text { rumah tangga ke lingkungan tanpa dilakukan pemilahan } \\
\text { sebelumnya }\end{array}$ & 23 & 77 \\
\hline 2. & $\begin{array}{l}\text { Apakah warga masyarakat Desa Berbek mengerti dampak yang } \\
\text { ditimbulkan ke lingkungan jika membuang limbah sampah } \\
\text { rumah tangga secara sembarangan }\end{array}$ & 75 & 25 \\
\hline 3. & $\begin{array}{l}\text { Apakah selama ini warga masyarakat Desa Berbek mengeluh } \\
\text { dengan bau yang ditimbulkan akibat adanya sampah rumah } \\
\text { tangga }\end{array}$ & 10 & 90 \\
\hline 4. & $\begin{array}{l}\text { Apakah sudah ada instansi atau universitas lain yang } \\
\text { memberikan pelatihan tentang pemilahan sampah rumah tangga }\end{array}$ & 100 & - \\
\hline 5. & $\begin{array}{l}\text { Apakah pemerintah Desa Berbek sudah memberikan petunjuk } \\
\text { atau instruksi untuk melakukan pemilahan sampah rumah tangga }\end{array}$ & 100 & - \\
\hline 6. & $\begin{array}{l}\text { Apakah warga masyarakat Desa Berbek sudah melakukan } \\
\text { pemilahan limbah sampah rumah tangga }\end{array}$ & 100 & - \\
\hline 7 & $\begin{array}{l}\text { Apakah warga masyarakat Desa Berbek mengerti manfaat dari } \\
\text { sampah anorganik rumah tangga jika dilakukan pengolahan }\end{array}$ & 100 & - \\
\hline
\end{tabular}




\begin{tabular}{|l|l|c|c|}
\hline No & \multicolumn{1}{|c|}{ Pertanyaan } & \multicolumn{1}{|c|}{ Persentase (\%) } \\
\cline { 2 - 4 } 8. & $\begin{array}{l}\text { Apakah warga masyarakat Desa Berbek sudah melakukan } \\
\text { pemanfaatan sampah norganik rumah tangga dengan menabung } \\
\text { di Bank Sampah }\end{array}$ & 100 & - \\
\hline 9. & $\begin{array}{l}\text { Apakah warga masyarakat Desa Berbek sebelumnya sudah } \\
\text { melakukan pemanfaatan sampah anorganik rumah tangga } \\
\text { menjadiproduk daur ulang }\end{array}$ & 100 & - \\
\hline 10. & $\begin{array}{l}\text { Apakah warga masyarakat Desa Berbek sudah melakukan } \\
\text { pembuatan pupuk organik dari limbah sampah rumah tangga } \\
\text { dengan teknologi takakura }\end{array}$ & 90 & 10 \\
\hline
\end{tabular}

Perubahan sosial atau hasil yang telah dicapai dengan adanya pengabdian yang telah dilakukan adalah warga masyarakat di Desa Berbek pada awalnya sebagian besar sampah rumah tangganya, yang termasuk didalamnya adalah sampah sisa konsumsi rumah tangga belum terolah dengan baik. Masyarakat desa Berbek sering kali mengeluhkan bau yang ditimbulkan akibat sampah rumah tangga yang tidak terolah. Selama ini belum ada suatu teknologi yang ditawarkan oleh suatu instansi untuk menyelesaikan permasalahan yang ada sehingga dosendosen Teknik Lingkungan tergerak untuk menyelesaikan permasalahan terkait dengan sampah rumah tangga untuk di pilah dan diolah secara sederhana dan murah sehingga permasalahan yang ada dapat terselesaikan. Warga desa selama ini belum mengenal cara sederhana dalam memilah sampah. Adapun yang mengenal hanya sebagian saja namun belum memahami prosedur yang baik untuk melakukannya.

Selama ini masyarakat Desa Berbek melakukannya membiarkan begitu saja sampah rumah tangga dan sampah organik lainnya sehingga sebagian besar warganya mengeluhkan akan adanya bau yang tidak sedap yang ditimbulkan akibat limbah tersebut. Berdasarkan pemantaun dan pendampingan setelah pelaksanaan penyuluhan tentang pemilahan limbah sampah rumah tangga, sudah terlihat perubahan yaitu dengan ditandai beberapa warga masyarakat yang sudah banyak menabung di Bank Sampah. Warga masyarakat Desa Berbek tidak mengalami kendala yang berarti karena masyarakat telah mendapatkan bekal dalam penyuluhan terkait dengan pemilahan dan pemanfaatan sampah secara ekonomi, baik untuk sampah organik maupun anorganik. Masyarakat sudah bisa merasakan hasilnya, dimana bau yang ditimbulkan dari sampah rumah tangga tersebut sudah berkurang. Hanya dalam waktu singkat masyarakat bisa merasakan apa yang telah warga lakukan. Selain itu masyarakat menyadari bahwa ada perbedaan yang signifikan terkait dengan kelestarian lingkungan.

Dilihat dari kondisi awalnya, masyarakat Desa Berbek belum pernah melakukan pemilahan limbah sampah baik dari kegiatan rumah tangga maupun sisa konsumsi dari warung makan. Selama ini masyarakat hanya mengenal sistem pemilahan sampah berdasarkan informasi yang diperoleh dari media informasi seperti televisi ataupun radio-radio serta media-media yang lain. Hal ini terbukti dengan hasil isian quisioner yang disebarkan oleh tim PPM dosen sebelum penyuluhan dan pelatihan dilakukan. Secara garis besar dari isian quisioner menunjukan bahwa sebagian besar masyarakatnya belum mengenal adanya suatu sistem pemilahan sampah organik dan non organik. 


\section{KESIMPULAN}

Kegiatan sosialisasi dan pelatihan pemilahan sampah dengan menggunakan Manual Pilah Sampah sebagai upaya untuk mendukung perkembangan Bank Sampah yang di ikuti oleh 30 orang masyarakat Desa Berbek Kecamatan Waru Kabupaten Sidoarjo berjalan dengan lancar. Pelaksanaan kegiatan dimulai dari jam 18.00 sampai jam 21.00 WIB. Kegiatan sosialisasi berisi tentang penyampaian materi mengenai pilah sampah dilanjutkan dengan pelatihan menggunakan Manual Pilah Sampah. Masyarakat desa sangat antusias dalam kegiatan ini. Diharapkan pasca kegiatan ini warga segera memilah sampah kering nya dan menyetorkan sampahnya di Bank Sampah dan dapat menunjang perkembangan Bank Sampah di Desa Berbek

\section{UCAPAN TERIMA KASIH}

Terima kasih kepada aparatur desa, kader lingkungan ,pokdarwis dan masyarakat Desa Berbek yang telah menerima dan membantu terlaksananya kegiatan pengabdian sehingga bisa terlaksana dengan baik dan lancar. Kepada Universitas PGRI Adi Buana Surabaya melalui Lembaga Penelitian dan Pengabdian Pada Masyarakat yang memberikan dukungan berupa dana pengabdian sehingga dapat melaksanakan kegiatan pengabdian kepada masyarakat dengan baik.

\section{REFERENSI}

Anonim. 2003. SNI 19-2454-2002 mengenai Tata Cara Teknik Operasional Pengelolaan Sampah Perkotaan.

Anonim. 2005. SNI 03-1733-2004 tentang Tata Cara Perencanaan Lingkungan Perumahan di Perkotaan.

Anonim. 2009. Undang-undang Nomor 18 Tahun 2008 tentang Pengelolaan
Sampah. Sekretariat Kementerian Pekerjaan Umum

Anonim. 2010. Peraturan Menteri Dalam Negeri Nomor 33 Tahun 2010 tentang Pedoman Pengelolaan Sampah. Sekretariat Kementrian Dalam Negeri

Asosiasi Pengusaha Daur Ulang Plastik, 2020, Bijak Mengelola Sampah Plastik, Webinar Pengelolaan Sampah Plastik

Biro Pusat Statistik, 2018, Jumlah Timbulan Sampah Kabupaten Sidoarjo Tahun http://sipsn.menlhk.go.id/?q=3adataumum\&field_f_wilayah_tid $=1516 \& f$ ield_kat_kota_tid $=8 \&$ field_periode $\mathrm{i}$ d_tid=2168

ESP (Environmental Services Program), 2008, Modul Pelatihan Pengelolaan Sampah Berbasis Masyarakat, Jakarta: ESP (Environmental Services Program), http://www.esp.or.id/wpcontent/uploads/pdf/cs/cs-ksncbwsm-solid.pdf

Kabupaten Sidoarjo Dalam Angka, 2020, Jumlah Penduduk Per Kecamatan di Sidoarjo https://sidoarjokab.bps.go.id/staticta ble/2016/01/21/37/luas-wilayah-kmdan-jumlah-penduduk-menurutkecamatan-hasil-sensus-penduduk1990-2000-2010.html

https://sidoarjokab.bps.go.id/publication/d ownload.html

Kementerian Pekerjaan Umum Badan Penelitian dan Pengembangan Pusat Penelitian dan Pengembangan Pemukiman, 2010, Modul Pengolahan Sampah Berbasis 3 R http://litbang.pu.go.id/puskim/source /pdf/Modul\%20Sampah\%203R.pdf 
Laporan IPKLH, 2018, Survey Indeks Perilaku Ketidakpedulian Lingkungan Hidup, Biro Pusat Statistik

Sistem Informasi Pengelolaan Sampah Nasional, 2020, Direktorat Pe ngelolaan Sampah Direktorat Jenderal Pengelolaan Sampah, Limbah dan B3 Kementerian Lingkungan Hidup dan Kehutanan,

Wildayanti, 2020, Pengelolaan Sampah Masa pandemi Covid 19, Astra EcoTalk 2020 Webinar Strategi Mengelola Sampah di Tengah Pandemi COVID-19 17 April 2020 